\title{
Partial Purification of Osteoclast-Activating Factor from Phytohemagglutinin-Stimulated Human Leukocytes
}

\author{
Richard A. Luben, Gregory R. Mundy, Clarence L. Trummel, and \\ LAWRENCE G. RAISZ \\ From the Departments of Pharmacology and Toxicology, Clinical Dentistry, \\ and Medicine, University of Rochester School of Medicine and Dentistry, \\ Rochester, New York 14642
}

\begin{abstract}
A в S T R A C T Osteoclast-activating factor (OAF) is a soluble mediator found in supernates of human peripheral leukocytes which have been cultured with antigens or phytomitogens. OAF is a potent stimulator of osteoclastic resorption of fetal bone in organ culture. The present studies were designed to characterize OAF chemically. Bone resorbing activity from supernates of leukocytes cultured without added plasma was not lost on dialysis using a membrane with a molecular weight cutoff of 3,500 , but was lost when heated to $60^{\circ} \mathrm{C}$ for 30 min. The activity was lost after treatment with trypsin or pronase but not after treatment with ribonuclease or neuraminidase. Papain, which inactivated parathyroid hormone at a concentration of $25 \mu \mathrm{g} / \mathrm{ml}$, did not inactivate $\mathrm{OAF}$ at $250 \mu \mathrm{g} / \mathrm{ml}$. OAF did not react with an antibody to bovine parathyroid hormone which crossreacts with human parathyroid hormone. OAF was also distinguished from active metabolites of vitamin $\mathrm{D}$ and from prostaglandin by extraction procedures and immunoassay for prostaglandin $\mathrm{E}_{2}$.

When the medium from activated leukocytes cultured with autologous plasma was fractionated by gel filtration on Sephadex, bone resorbing activity eluted both with plasma proteins and in lower molecular weight fractions. However, when medium from leukocytes cultured without added plasma was chromatographed, all the OAF activity was eluted in a sharp low molecular weight peak located between chymotrypsinogen $(25,000$ molecular weight) and ribonuclease A (13,700 molecular weight). This peak contained about $4 \%$ of the total protein originally present in the supernate. Its activity was destroyed by overnight incubation at $37^{\circ} \mathrm{C}$ at $\mathrm{pH} 6$ or 8 , but not at $\mathrm{pH} 7.2$. After incubation at $4^{\circ} \mathrm{C}$, the activity was lost at $\mathrm{pH} 3$ or 10 , but not at $\mathrm{pH} 4-9$.
\end{abstract}

Received for publication 1 November 1973 and in revised form 4 January 1974.
The active fraction from Sephadex G-100 was therefore chromatographed at $\mathrm{pH} 7.2$ on DEAE cellulose and carboxymethyl cellulose. The active material was not adsorbed; however, about sevenfold further purification was achieved by removal of contaminants. The material obtained after sequential Sephadex, DEAE and, carboxymethyl cellulose chromatography stimulated resorption of fetal rat bone in culture at concentrations of 0.75-3 $\mu \mathrm{g}$ protein $/ \mathrm{ml}$, indicating that this preparation of $\mathrm{OAF}$ was nearly as potent as bovine parathyroid hormone in this system.

\section{INTRODUCTION}

Local resorption of bone is associated with chronic inflammation in such disorders as periodontal disease, rheumatoid arthritis, and chronic osteomyelitis. Cultures of cells associated with chronic inflammation, particularly lymphocytes, can produce soluble factors with a variety of biological activities (1). The production of these factors is generally increased when the cells are stimulated by antigens to which the donor has developed cellular immunity or by nonspecific mitogens, such as phytohemagglutinin (PHA). ' Recently a new soluble mediator in supernates of activated human peripheral leukocyte cultures was identified by its ability to stimulate resorption of fetal rat bone in organ culture (2). The activity was present in leukocyte cultures stimulated by a solubilized dental plaque antigen or by PHA. The mediator was termed osteoclast-activating factor (OAF), because treated bones showed large numbers of active osteoclasts which appeared to be responsible

${ }^{1}$ Abbreviations used in this paper: CM, carboxymethyl; $\mathrm{K}_{\mathrm{D}}$, partition coefficient; MIF, migration inhibition factor; $\mathrm{OAF}$, osteoclast activating factor; $\mathrm{PGE}_{2}$, prostaglandin $\mathrm{E}_{2}$; $\mathrm{PHA}$, phytohemagglutinin; $\mathrm{PTH}$, parathyroid hormone. 
TABLE I

OAF Produced by Human Leukocyte Cultures with and without $P H A$

\begin{tabular}{lcc}
\hline & $\begin{array}{c}{\left[{ }^{2} \mathrm{H}\right] \mathrm{TdR}} \\
\text { incorporation, } \\
\text { cpm/culture }\end{array}$ & $\begin{array}{c}48 \mathrm{~h} \\
\text { 45Ca release, } \\
\text { treated/control } \\
\text { ratio }\end{array}$ \\
\hline $\begin{array}{c}\text { Leukocyte cultures } \\
\text { 20\% plasma - PHA }\end{array}$ & $483 \pm 114$ & $1.19 \pm 0.11$ \\
20\% plasma + PHA & $14,123 \pm 589$ & $1.61 \pm 0.17^{*}$ \\
No plasma - PHA & $230 \pm 71$ & $0.96 \pm 0.16$ \\
No plasma + PHA & $18,480 \pm 332$ & $2.45 \pm 0.20^{*}$ \\
$\begin{array}{c}\text { Culture medium } \\
1 \% \text { PHA }\end{array}$ & - & $0.96 \pm 0.08$ \\
$10 \%$ PHA & - & $0.89 \pm 0.07$ \\
\hline
\end{tabular}

Human leukocytes were cultures (approximately $10^{6}$ cells in $1 \mathrm{ml}$ of BGJ medium), with or without $20 \%$ autologous plasma, and with or without PHA. At the end of 3 days of culture, the supernatant medium was removed, and the cells were incubated with $\left[{ }^{3} \mathrm{H}\right] \mathrm{TdR}, 1 \mu \mathrm{Ci}$ /culture, in $\mathrm{BGJ}$ for $4.5 \mathrm{~h}$. The incorporation of ${ }^{3} \mathrm{H}$ into cellular material precipitated with cold trichloroacetic acid $(5 \%)$ was then determined. Incorporation values are mean $\pm \mathrm{SEM}$ for six cultures. Supernates from parallel cultures not labeled with $\left[{ }^{3} \mathrm{H}\right] \mathrm{TdR}$ were diluted 1:1 with fresh BGJ and assayed for stimulation of bone resorption in organ culture. Fresh BGJ medium with added PHA which had not been used for leukocyte cultures was also assayed. Results are expressed as mean \pm SEM treated/control ratios for four pairs of bones.

* Significantly different from $1.0(P<0.05)$.

for the increased resorption. The present studies were designed to characterize chemically the activity in supernates of leukocyte cultures stimulated by PHA and to isolate the active fraction. OAF was found to be a protease-sensitive macromolecule which could be distinguished from stimulators of bone resorption which have been chemically identified previously, such as parathyroid hormone (PTH), 1,25-dihydroxycholecalciferol $\left(1,25-[\mathrm{OH}]_{2} \mathrm{D}_{3}\right)$, and prostaglandin $\mathrm{E}_{2}\left(\mathrm{PGE}_{2}\right)$.

\section{METHODS}

Leukocyte cultures. Human peripheral leukocytes were cultured as described previously (2). White cell-rich plasma and buffy coat were removed from settled heparinized blood. In initial experiments, the cells were spun down and resuspended in medium RPMI 1640 with $20 \%$ autologous plasma. In most experiments, the cells were centrifuged, the plasma was removed as completely as possible, and the cell pellet was resuspended at approximately $10^{\circ}$ cells $/ \mathrm{ml}$ (60-80\% mononuclear cells) in BGJ medium (3), with or without added PHA (1\% Gibco crude PHA [Grand Island Biological Co., Grand Island, N. Y.], approximately 30 $\mu \mathrm{g} / \mathrm{ml}$ ). The medium was usually harvested at 24 and $72 \mathrm{~h}$. Pooled culture medium was sterilized by millipore filtration, concentrated 10 - to 20 -fold by ultrafiltration using Amicon PM10 membranes (Amicon Corp., Lexington, Mass.), and stored frozen at $-20^{\circ} \mathrm{C}$. Concentrated media were diluted with fresh BGJ before assay, or used directly for enzyme studies or chromatography.

Bone resorption assays. The method for measuring bone resorption in organ culture has been described previously (3). Rats were injected with $0.4 \mathrm{mCi}$ of ${ }^{45} \mathrm{CaCl}_{2}$ on the 18th day of gestation. On the 19th day, the fetuses were removed and the shafts of the radius and ulna dissected and cultured in BGJ with $1 \mathrm{mg} / \mathrm{ml}$ bovine serum albumin or $5 \%$ human plasma (both heat inactivated at $60^{\circ} \mathrm{C}$ for $30 \mathrm{~min}$ ). After a $24-$ to 48 -h period of preculture in control medium, which served to remove much of the exchangeable ${ }^{45} \mathrm{Ca}$, the bones were transferred to test or control media for assay. The test media consisted of appropriate dilutions of leukocyte culture medium or one of the materials described below. Control values for ${ }^{45} \mathrm{Ca}$ release were obtained by culturing bones in BGJ medium containing 1 $\mathrm{mg} / \mathrm{ml}$ heat-inactivated bovine serum albumin or $5 \%$ heatinactivated human plasma (for enzyme studies). After 2-4 days in culture, ${ }^{45} \mathrm{Ca}$ release from bones in the test medium was compared to ${ }^{45} \mathrm{Ca}$ release in control cultures. When paired radii or ulnae from the same fetus were used, a treated-to-control ratio was calculated. In most experiments, treated bones were not paired with controls from the same fetus. Instead, a group of bones from each litter were used as controls, and the remaining bones were divided among the treatment groups. In these experiments, the percentage release of total ${ }^{45} \mathrm{Ca}$ was determined by

TABLE II

Dialysis, Heat Inactivation, and Ultrafiltration of $O A F$

\begin{tabular}{cll}
\hline Experiment & \multicolumn{1}{c}{$\begin{array}{c}\text { 48 } \mathrm{h} \\
\text { 45Ca release, } \\
\text { treated/control } \\
\text { ratio }\end{array}$} \\
\hline A & Treatment & $2.44 \pm 0.13^{*}$ \\
& None & $1.17 \pm 0.21$ \\
B & Dialyzed & $2.26 \pm 0.39^{*}$ \\
& None & $2.20 \pm 0.31^{*}$ \\
& Dialyzed & \\
& Heated $\left(60^{\circ}, 30\right.$ min, & $1.09 \pm 0.16$ \\
C & $\quad$ no dialysis $)$ & $2.53 \pm 0.08^{*}$ \\
& None & $1.15 \pm 0.23$ \\
& PM10 filtrate & $2.25 \pm 0.38^{*}$ \\
& PM10 retentate & $1.94 \pm 0.14^{*}$ \\
& XM50 filtrate & $1.79 \pm 0.07^{*}$
\end{tabular}

Medium from PHA-stimulated leukocyte cultures without added plasma was treated as indicated, then diluted with fresh medium and assayed for bone-resorbing activity. Experiment $\mathrm{A}$ : dialysis against $\mathrm{BGJ}$, using $\mathrm{Fisher}$ dialyzer tubing (Fisher Scientific Co., Pittsburgh, Pa.), nominal molecular weight cutoff about 12,000. Experiment B: dialysis against BGJ using Spectrapor 3 dialysis membranes (see Methods), nominal molecular weight cutoff about 3,500. Experiment C: samples concentrated to one-fourth the original volume using Amicon filters PM10 or XM50. Retentates were diluted back to the original volume with $\mathrm{BGJ}$ for assay, while filtrates were assayed directly. PM10 and XM50 membranes have nominal molecular weight cutoffs of 10,000 and 50,000 , respectively.

* Significantly different from $1.0(P<0.05)$. 
measuring radioactivity in both bone and medium and was calculated as follows: percent release $=($ medium $\mathrm{dpm} /$ [medium dpm + bone dpm]) $\times 100$.

Enzyme digestion. Trypsin (lyophilized, salt-free $1 \times$ crystallized, $150 \mathrm{U} / \mathrm{mg}$ protein) was obtained from Worthington Biochemical Corp., Freehold, N. J. Enzymes, obtained from Sigma Chemical Co., St. Louis, Mo., were papain $(2 \times$ crystallized, $30 \mathrm{U} / \mathrm{mg}$ protein), pronase (protease type VI, $3 \mathrm{U} / \mathrm{mg}$ protein), ribonuclease $(5 \times$ crystallized type I-A, $75 \mathrm{Kunitz} \mathrm{U} / \mathrm{mg}$ protein), and neuraminidase (type $\mathrm{V}, 12 \mathrm{U} / \mu \mathrm{g}$ solid, using bovine submaxillary mucin as substrate). The effects of incubation with enzymes were tested on samples of $10 \times$ concentrated leukocyte supernate and purified bovine parathyroid hormone (kindly provided by Dr. W. Y. W. Au). The samples were exposed to enzymes in BGJ without added albumin or plasma at $37^{\circ} \mathrm{C}$ for $1 \mathrm{~h}$ under an atmosphere of $5 \% \mathrm{CO}_{2}$ in air, $\mathrm{pH}$ approximately 7.3-7.4. After incubation, the samples were diluted 10 -fold with BGJ containing 5\% heat-inactivated human plasma. The final concentrations of enzymes were those which, in preliminary experiments, had been shown to have no effect on control resorption, and additional control cultures with enzyme were used in each experiment to confirm this. Enzymes which did not destroy OAF activity were assayed by using standard substrates after incubation in $\mathrm{BGJ}$ for $1 \mathrm{~h}$ at $37^{\circ} \mathrm{C}$ in $5 \% \mathrm{CO}_{2}$. Bovine submaxillary mucin (Sigma Chemical Co.) was used as substrate for neuraminidase, Escherichia coli RNA (Calbiochem, San Diego, Calif.) for ribonuclease, and $\alpha-N$-benzoyl-L-arginine ethyl ester (Sigma Chemical Co.) for papain. Under these conditions, neuraminidase retained $15 \%$, ribonuclease $70 \%$, and papain $19 \%$ of their originally specified specific activities toward these substrates.

Extraction procedures. Concentrated leukocyte culture media were extracted with solvents which are known to remove the potent lipid soluble bone resorbing agents, $1,25-(\mathrm{OH})_{2} \mathrm{D}_{3}(4,5)$, and $\mathrm{PGE}_{2}(6,7)$ from biological samples. OAF samples, control medium, and medium to which authentic $1,25-(\mathrm{OH})_{2} \mathrm{D}_{3}$ or $\mathrm{PGE}_{2}$ had been added were prepared and extracted either with chloroform-methanol $(1: 1)$ followed by chloroform (for vitamin D metabolites), or with redistilled ethyl acetate after adjustment of the medium to $\mathrm{pH} 3.5$ with glacial acetic acid (for $\mathrm{PGE}_{2}$ ). Extraction was repeated three times, and the organic phases were pooled and dried under nitrogen, and the residue was dissolved with BGJ for assay.

Gel filtration chromatography. All chromatographic steps were carried out at $4^{\circ} \mathrm{C}$. $2-3 \mathrm{ml}$ of concentrated leukocyte supernates was applied to columns of Sephadex G-150 or G-100 equilibrated in $0.02 \mathrm{M}$ sodium phosphate buffer with $0.15 \mathrm{M} \mathrm{NaCl}, \mathrm{pH} \mathrm{7.2,} \mathrm{and} \mathrm{eluted} \mathrm{with} \mathrm{buffer.} \mathrm{The} \mathrm{frac-}$ tions were pooled and dialyzed against BGJ at a phosphate concentration adjusted to produce a final concentration of $1.0 \mathrm{mM}$. The dialysis membrane used was boiled Spectrapor 3 (Spectrum Medical Industries, Inc., Los Angeles, Calif.), with a nominal molecular weight cutoff of 3,500. Dialyzed fractions were further diluted with fresh BGJ for assay. Protein was determined by the method of Lowry, Rosebrough, Farr, and Randall (8). The elution volumes of column fractions were used to calculate the partition coefficient $\left(K_{D}\right)$, both for $O A F$ activity and for standard calibration proteins (Pharmacia Calibration Kit, Pharmacia Fine Chemicals, Inc., Piscataway, N. J.). $\mathbf{K}_{\mathbf{D}}$ was calculated as follows: $K_{D}=\left(V_{0}-V_{0}\right) / V_{1}$, where $V_{\bullet}$ was the peak elution volume of the material in question, $V_{0}$ was the peak elution volume for blue dextran, and $V_{1}$

\author{
TABLE: III \\ Effect of Enzyme Digestion on Bone Resorbing Activity \\ of $O A F$ and $P T H$
}

\begin{tabular}{cllll}
\hline & & \multicolumn{2}{c}{ Percent release of ${ }^{45} \mathrm{Ca}$} \\
\cline { 3 - 5 } Experiment & \multicolumn{1}{c}{ Digestion } & Control & OAF & PTH \\
\hline A, medium & None & $20 \pm 1$ & $37 \pm 4^{*}$ & $38 \pm 3^{*}$ \\
treated & Trypsin $40 \mu \mathrm{g} / \mathrm{ml}$ & $19 \pm 1$ & $43 \pm 4^{*}$ & $20 \pm 2$ \\
& Trypsin $400 \mu \mathrm{g} / \mathrm{ml}$ & $20 \pm 1$ & $18 \pm 1$ & $19 \pm 2$ \\
& Neuraminidase $400 \mu \mathrm{g} / \mathrm{ml}$ & $19 \pm 1$ & $42 \pm 4^{*}$ & $37 \pm 4^{*}$ \\
& Ribonuclease $100 \mu \mathrm{g} / \mathrm{ml}$ & $22 \pm 2$ & $33 \pm 5^{*}$ & $45 \pm 4^{*}$ \\
& Papain $25 \mu \mathrm{g} / \mathrm{ml}$ & $20 \pm 1$ & $46 \pm 8^{*}$ & $19 \pm 1$ \\
B, medium & None & $13 \pm 1$ & $33 \pm 8^{*}$ & - \\
treated & Papain $250 \mu \mathrm{g} / \mathrm{ml}$ & $12 \pm 1$ & $30 \pm 2^{*}$ & - \\
& Pronase $500 \mu \mathrm{g} / \mathrm{ml}$ & $11 \pm 1$ & $12 \pm 1$ & - \\
C, Bone & None & $20 \pm 1$ & $53 \pm 3^{*}$ & - \\
treated & Trypsin $40 \mu \mathrm{g} / \mathrm{ml} \mathrm{1} \mathrm{day}$ & $22 \pm 2$ & $46 \pm 1^{*}$ & \\
\end{tabular}

In experiments $A$ and $B$, media containing OAF, $10 \times$ concentrate, or PTH, $10 \mu \mathrm{g} / \mathrm{ml}$, and control media were digested with enzymes added at the indicated concentration for $1 \mathrm{~h}$ at $37^{\circ} \mathrm{C}$, followed by 10 -fold dilution with fresh medium before assay. In experiment $C$, bones were incubated for 1 day, with or without trypsin, washed with fresh medium, and placed in assay medium. Values are mean $\pm \mathrm{SEM}$ (four to eight bones per point). * Significant difference from control $(P<0.05)$.

was the difference between the peak elution volumes of blue dextran and tritiated water under the operating conditions used. $K_{D}$ vs. $\log$ (molecular weight) gave a linear plot for the calibration proteins used (9).

Ion exchange chromatography. Pooled active fractions from Sephadex G-100 chromatography were dialyzed against $0.05 \mathrm{M}$ Tris- $\mathrm{HCl}, \mathrm{pH} 7.2$, or against $0.02 \mathrm{M}$ Hepes, $\mathrm{pH} 7$ (Gibco), and chromatographed on columns of DEAE cellulose (Whatman DE 52) or carboxymethyl (CM cellulose (Whatman CM 32), respectively. The columns were washed with starting buffer and then eluted with a linear gradient of $0-0.5 \mathrm{M} \mathrm{NaCl}$ in starting buffer. The $\mathrm{CM}$ cellulose column was washed with $1.0 \mathrm{M} \mathrm{NaCl}$ after elution. The fractions were dialyzed against BGJ for assay as described above.

Immunoassays. Leukocyte culture supernates were assayed directly for immunoreactive PTH (10) by Dr. Charles Hawker (Upjohn Co., Kalamazoo, Mich.). Ethyl acetate extracts of acidified supernates were assayed by using a prostaglandin $\mathrm{E}$ immunoassay kit (11) (Clinical Assays, Inc., Cambridge, Mass.) by Dr. J. M. Goodson (University of California at San Francisco School of Dentistry).

\section{RESULTS}

Supernates of human peripheral leukocyte cultures activated with PHA contained bone-resorbing activity, while supernates from unstimulated leukocytes were inactive (Table I). PHA alone had no effect on bone resorption. Leukocytes cultured without added serum showed as great a stimulation of thymidine uptake and released as much OAF as did leukocytes cultured with $20 \%$ autologous plasma. When OAF-containing media were dialyzed by using cellulose membranes with a nominal molecular weight cutoff of 12,000 , much of the activity was lost (Table II), but using Spectrapor 3 


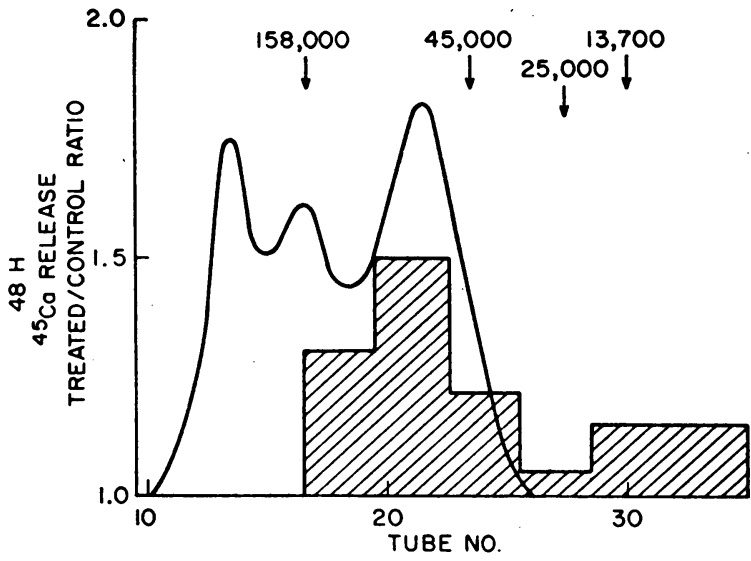

FIGURE 1 Gel filtration of medium from PHA-stimulated leukocyte cultures containing $20 \%$ plasma. Concentrated dialyzed medium was placed on a column $(2.5 \times 35 \mathrm{~cm})$ of Sephadex G-150 and eluted with $0.02 \mathrm{M}$ sodium phosphate, $0.15 \mathrm{M} \mathrm{NaCl}, \mathrm{pH}$ 7.2. The solid line represents absorbance at $280 \mathrm{~nm}$; shaded bars represent the stimulation of bone resorption by pooled fractions from the areas indicated. Bone resorption was estimated from the release of ${ }^{45} \mathrm{Ca}$ by fetal rat bones in tissue culture containing aliquots of the pooled, dialyzed, and concentrated fractions (see Methods) compared with similarly treated fractions of control medium incubated without cells. The arrows at the top of the chromatogram represent the peak elution volumes of aldolase $(158,000)$, ovalbumin $(45,000)$, chymotrypsinogen $(25,000)$, and ribonuclease A $(13,700)$.

with a nominal cutoff of about 3,500 , all the activity was retained. Heating to $60^{\circ} \mathrm{C}$ for 30 min inactivated OAF in supernates containing no added plasma. Little or no OAF was filterable through an Amicon PM10 filter, but a substantial fraction passed through an XM50 filter. There was no measurable loss of biological activity during ultrafiltration. These results suggested that the molecular weight of OAF was between 10,000 and 50,000 , nominal values for $95 \%$ rejection of globular proteins by the PM10 and XM50 filters, respectively.

OAF was inactivated (Table III) by treatment with trypsin $(400 \mu \mathrm{g} / \mathrm{ml})$ or pronase $(500 \mu \mathrm{g} / \mathrm{ml})$, but not by neuraminidase $(400 \mu \mathrm{g} / \mathrm{ml})$ ribonuclease $(100 \mu \mathrm{g} /$ $\mathrm{ml})$ nor papain $(250 \mu \mathrm{g} / \mathrm{ml})$. Bovine PTH was also resistant to neuraminidase and ribonuclease, but was inactivated by trypsin at $40 \mu \mathrm{g} / \mathrm{ml}$ and papain at $25 \mu \mathrm{g} /$ $\mathrm{ml}$. In a separate study, PTH was inactivated by 10 $\mu \mathrm{g} / \mathrm{ml}$ trypsin (data not shown). Pretreatment of bone with trypsin at $40 \mu \mathrm{g} / \mathrm{ml}$, the concentration present in bone cultures after dilution of the $400 \mu \mathrm{g} / \mathrm{ml}$ incubation mixture in the inactivation experiments, did not block the subsequent resorptive response of bone to OAF.

The fact that OAF activity was not lost on dialysis with Spectrapor 3 or on ultrafiltration with PM10 argued against the activity being due to a prostaglandin or vitamin D metabolite. However, since there could have been retention of such materials by protein binding, active OAF samples were extracted repeatedly with lipid solvents which can remove these materials (Table IV). The bone-resorbing activity of $1,25-(\mathrm{OH})_{2} \mathrm{D}_{3}$ was extracted from BGJ medium with chloroform-methanol, while the activity of $\mathrm{PGE}_{2}$ was extracted with ethyl acetate after acidification (Table IV). Neither extraction procedure yielded biological activity from supernates containing OAF. By immunoassay, the supernate with maximal OAF activity contained $0.5 \mathrm{ng} / \mathrm{ml}$ of bovine PTH equivalent. Much of this could be ascribed to nonspecific displacement of labeled hormone, since BGJ alone gave a value of $0.4 \mathrm{ng} / \mathrm{ml}$. There was no detectable PGEa by immunoassay in the ethyl acetate extracts under conditions which should have detected as little as $2 \times 10^{-8} \mathrm{M} \mathrm{PGE}_{2}$ in the original medium.

Initial OAF samples obtained from leukocytes cultured in $20 \%$ autologous plasma showed widely dispersed activity when chromatographed on Sephadex G-150 (Fig. 1). The greatest biological activity eluted in the albumin fraction, but activity was also found in lower molecular weight fractions. Fractions of supernates from inactive leukocyte cultures showed no bone-resorbing activity when compared with the same fractions from control media, which had been incubated without cells. When OAF was obtained from supernates of leukocytes cultured without added serum, there was no longer any detectable biological activity in the albumin region (Fig. 2), and the activity now eluted as a discrete symmetrical peak on Sephadex G-100 after chymotrypsinogen $(25,000$ molecular weight) and before ribonuclease A (13,700 molecular weight). No bone-resorbing activity was found in any fraction of medium from unstimulated cultures ( $1 \%$ PHA added after culture). The OAF peak had a $K_{D}$ of 0.52 . The active fractions from the G-100 column contained only about $4 \%$ as much protein as the original supernate (Table $\mathrm{V}$ ) and showed a similar dose-response curve to crude OAF with no evidence of loss of activity on the column (Fig. 3).

TABLE IV

Extraction of Bone Resorbing Activity from BGJ Culture Medium by Specific Organic Solvents

\begin{tabular}{lccc}
\hline & \multicolumn{3}{c}{ Percent release of ${ }^{45 C} \mathrm{Ca}$} \\
\cline { 2 - 4 } \multicolumn{1}{c}{ Sample } & $\begin{array}{c}\text { No } \\
\text { extraction }\end{array}$ & $\begin{array}{c}\text { Chloroform/ } \\
\text { methanol }\end{array}$ & $\begin{array}{c}\text { Ethyl } \\
\text { acetate }\end{array}$ \\
\hline $\mathrm{BGJ}$ & $14 \pm 2$ & $12 \pm 1$ & $15 \pm 2$ \\
$1,25-(\mathrm{OH})_{2} \mathrm{D}_{2}(10 \mathrm{ng} / \mathrm{ml})$ & $30 \pm 3^{*}$ & $21 \pm 2^{*}$ & - \\
$\mathrm{PGE}\left(10^{-5} \mathrm{M}\right)$ & $33 \pm 8^{*}$ & - & $31 \pm 4^{*}$ \\
$\mathrm{OAF}$ & $38 \pm 4^{*}$ & $15 \pm 2$ & $16 \pm 2$ \\
\hline
\end{tabular}

Samples containing $1,25-(\mathrm{OH})_{2} \mathrm{D}_{3}$ or $\mathrm{PGE}_{2}$ were extracted three times using equal volumes of solvent and sample. Pooled extracts were dried under nitrogen at $4^{\circ} \mathrm{C}$ and reconstituted to $85 \%$ of the volume of the original sample with BGJ medium for assay. Values are mean $\pm \operatorname{SEM}(n=4)$.

* Significantly different from control BGJ $(P<0.05)$. 
When partially purified OAF from G-100 columns was incubated at $37^{\circ} \mathrm{C}$ overnight at $\mathrm{pH} 6$ or 8.1 , activity was lost (Fig. 4), but activity was not lost at $\mathrm{pH} 7.4$. When incubated at $4^{\circ} \mathrm{C}$ overnight, the activity was completely lost only at $\mathrm{pH} 3$ or 10 , and significant activity was retained over a range of $4.0-8.5$ (Fig. 4). However, the maximal recovery appeared to be at neutral $\mathrm{pH}$. Because of these results, further purification was attempted at $\mathrm{pH} 7.2$ by using DEAE and CM cellulose. The activity was recovered in the initial buffer wash and not retarded on either column. There even appeared to be a slight increase in activity in the eluate from the CM cellulose column (Fig. 5). Although OAF was not retained on DEAE or CM cellulose, some contaminants were apparently removed, since the protein content was reduced by about seven-fold without loss of biological activity. Attempts to purify OAF further on $\mathrm{CM}$ cellulose at $\mathrm{pH} 5.3$ were unsuccessful. This was ascribed to inactivation, since no biological activity was found either in the column fractions or in the original sample after dialysis against $\mathrm{pH} 5.3$ ammonium acetate buffer.

\section{DISCUSSION}

The studies reported here were designed to compare the chemical characteristics of OAF with those of other stimulators of bone resorption. The original studies (2) of bone-resorbing activity in supernates of activated leukocyte cultures did not distinguish OAF from other agents known to cause bone resorption, such as PTH, active metabolites of vitamin $\mathrm{D}$, or prostaglandins. The fact that $\mathrm{OAF}$ is heat labile and nondialyzable suggests that it is macromolecular, like PTH. However, OAF

TABLE V

Protein Content of Purified OAF Fractions

\begin{tabular}{lc}
\hline \multicolumn{1}{c}{ Active fraction } & $\begin{array}{c}\text { Protein } \\
\text { content }\end{array}$ \\
\hline & $\mu g / m l$ \\
Crude OAF & 514 \\
G-100 OAF & 21.4 \\
CMC & 9.0 \\
DEAE & 6.1 \\
DEAE-CMC (sequential) & 3.0
\end{tabular}

Leukocyte culture medium ("crude OAF") was fractionated on Sephadex G-100. Active fractions were pooled and passed through columns of carboxymethyl-cellulose (CMC), DEAEcellulose, or DEAE-cellulose followed by CMC. The active eluates were concentrated and analyzed for protein, using bovine serum albumin as standard and expressed as protein concentration per milliliter of the original leukocyte culture supernate, which contained maximal bone resorbing activity. These purification procedures caused no measurable loss of biological activity (see Figs. 3 and 5).
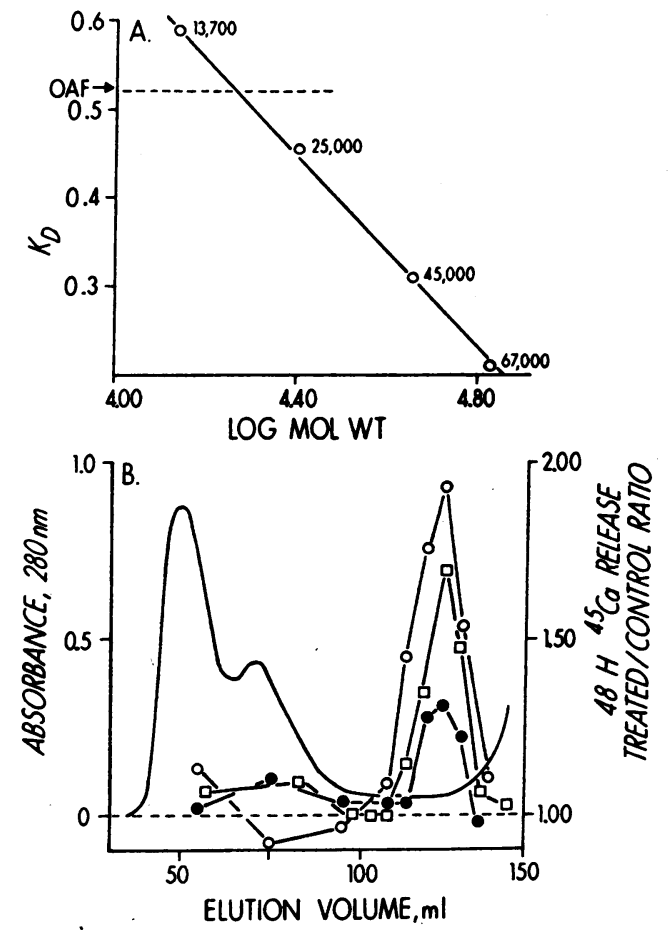

FIGURE 2 Gel filtration of medium from PHA-stimulated leukocyte cultures without added serum. Concentrated medium was placed on a column $(2.5 \times 45 \mathrm{~cm})$ of Sephadex G-100 and eluted with $0.02 \mathrm{M}$ sodium phosphate, $0.15 \mathrm{M}$ $\mathrm{NaCl}, \mathrm{pH}$ 7.2. (A). Calibration of the column with standard proteins. Molecular weight values represented are bovine serum albumin $(67,000)$, ovalbumin $(45,000)$, chymotrypsinogen $(25,000)$, and ribonuclease A $(13,700)$. (B) Chromatography of active OAF samples. Column fractions were pooled, dialyzed against BGJ, and assayed for boneresorbing activity. The smooth curve is absorbance at 280 $\mathrm{nm}$; the connected points represent activity of media from three separate leukocyte cultures from two normal donors. Control media for the bone resorption assays were BGJ with $1 \mathrm{mg} / \mathrm{ml}$ bovine serum albumin.

can be distinguished chemically from PTH by several criteria. OAF is more sensitive to heat and acid than $\mathrm{PTH}$, which can be extracted from parathyroid glands in a biologically active form by using $0.2 \mathrm{~N} \mathrm{HCl}$ at $100^{\circ} \mathrm{C}$ (12). OAF is considerably more resistant than PTH to inactivation by either trypsin or papain. In addition, supernates containing OAF activity did not react with an antibody to bovine $\mathrm{PTH}$, which cross-reacts with human PTH at physiological concentrations (10). Since the antibody may not cross-react with the biologically active sequence of $\mathrm{PTH}$, it is conceivable that $\mathrm{OAF}$ and $\mathrm{PTH}$ have sequences in common in the active part of the molecules. The complete recovery of OAF as a sharp peak from Sephadex without special pretreatment of the gel is also in contrast to the reported behavior of PTH (13). 


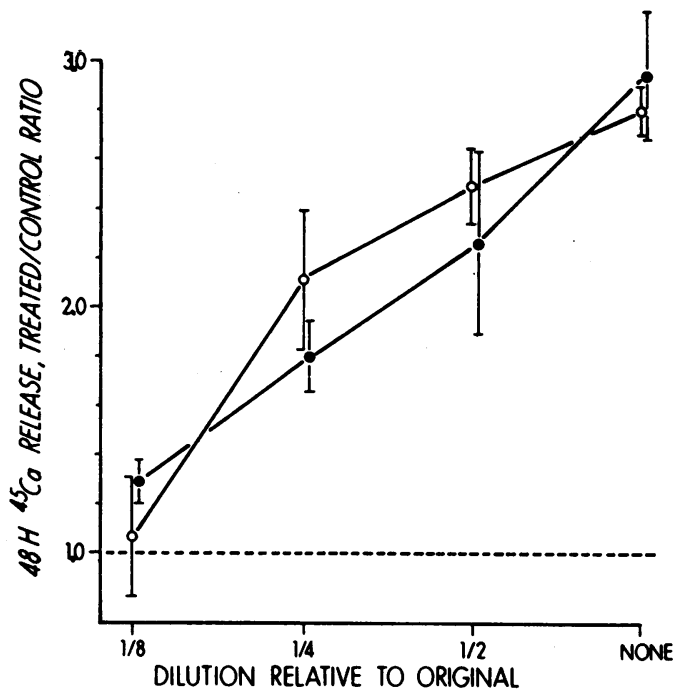

Figure 3 Log dose-response curves for crude and purified OAF. Medium from PHA-stimulated leukocyte cultures ("crude OAF") was serially diluted and assayed for boneresorbing activity (open circles). Pooled active fractions from G-100 chromatography ("purified OAF") were concentrated to the same volume as the original culture medium used for the column run, dialyzed against BGJ medium, then diluted serially for assay (solid circles). Values are mean $\pm \mathrm{SEM}$ for four pairs of bones per point.

OAF was also distinguished by several criteria from the active metabolites of vitamin $\mathrm{D}$ or prostaglandins. Retention of full OAF activity during dialysis using a membrane with a 3,500 molecular weight cutoff suggests that the activity was not due to a small molecule. Moreover, no bone-resorbing activity could be recovered by extraction with lipid solvents of active samples containing $\mathrm{OAF}$, although these procedures did result in recovery of biologically active $1,25(\mathrm{OH})_{2} \mathrm{D}_{3}$ and $\mathrm{PGE}_{2}$. Finally, we could not detect $\mathrm{PGE}_{2}$ by immunoassay in extracts of OAF-containing media. These results do not rule out the possibility that OAF activity depends on the combination of a protein moiety with some active group resembling prostaglandins or vitamin D metabolites, perhaps as a covalently bonded complex.

Enzyme inactivation studies indicated that OAF activity was dependent on a protein moiety. Failure to inactivate $\mathrm{OAF}$ with ribonuclease or neuraminidase indicates that nucleic acids are probably not an important component and that terminal sialic acid residues are either absent or not required for biologic activity. Chromatographic studies also indicated that OAF was a macromolecule, which was not highly charged on the basis of its behavior on ion exchange resins. When OAF was produced in cultures containing added plasma, the elution pattern on Sephadex G-100 was very disperse. This may have been, the result of aggregation, binding to plasma proteins, or distortion of the elution pattern by the large amount of protein which had to be placed on the column to recover significant amounts of activity. Moreover, it is possible that OAF produced by lymphocytes in the presence of added autologous plasma is heterogeneous and that these different active fractions represent different biologically active molecules.

When OAF was produced by normal human leukocytes in the absence of added plasma, a single symmetrical peak of biological activity eluted from Sephadex G-100 with a $K_{D}$ of about 0.52 . When compared to the elution for globular proteins, this value would correspond to a mass of about 18,000 daltons. However, since we do not known whether OAF is a globular protein, this may not represent the true molecular weight. Sephadex-purified OAF was relatively stable at neutral $\mathrm{pH}$, but rapidly inactivated at both high and low $\mathrm{pH}$, particularly at $37^{\circ} \mathrm{C}$. Since these preparations were not pure, we cannot determine whether this is the result of activation of enzymes present in the fraction or direct inactivation of OAF. Further purification of OAF was attempted by using DEAE cellulose and CM cellulose columns at neutral $\mathrm{pH}$. The biological activity was eluted with the buffer and not adsorbed to the resin. Nevertheless, some purification resulted because of the removal of contaminants, and the final product was biologically active

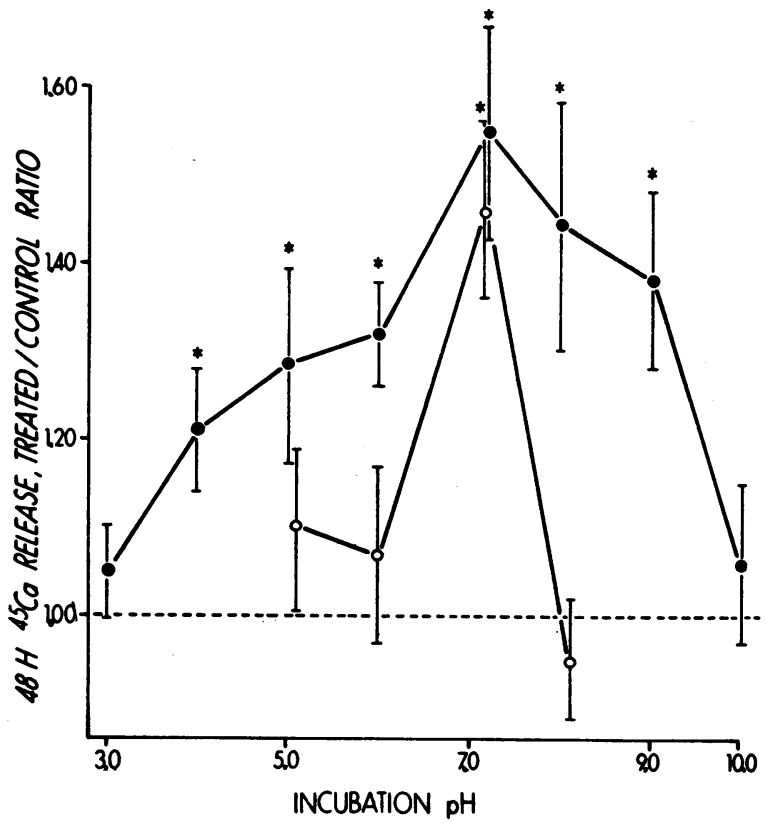

FIGURE 4 Effect of $\mathrm{pH}$ on OAF activity. Purified OAF from G-100 chromatography was adjusted (in column buffer) to the indicated $\mathrm{pH}$ values, stored overnight at $4^{\circ} \mathrm{C}$ or $37^{\circ} \mathrm{C}$, then dialyzed against $\mathrm{BGJ}$ medium before assay of bone-resorbing activity. Values are mean $\pm S E M$ for four to eight pairs of bones per point. $\bullet, 4^{\circ} \mathrm{C} ; \mathrm{O}, 37^{\circ} \mathrm{C}$; *, significantly different from control $(P<0.05)$. 
over a range of $0.75-3 \mu \mathrm{g} / \mathrm{ml}$ of protein concentration, not much greater than the concentrations of bovine $\mathrm{PTH}$ $(0.1-1.0 \mu \mathrm{g} / \mathrm{ml})$ which give equivalent stimulation of resorption in this culture system (3). It is likely that this preparation is still quite impure and, therefore, that the concentration of active OAF is much lower than suggested by the protein analysis. On the other hand, we have no evidence that OAF contains only protein. It could conceivably contain substantial amounts of carbohydrate or lipid. However, if it were a highly acidic glycoprotein, then one might have expected it to bind to DEAE cellulose, and if the lipid moiety were large, one might have expected to observe extraction of the active material with lipid solvents.

OAF appears to be chemically distinct from previously characterized lymphokines produced by cultures of activated human leukocytes. Human macrophage migration inhibition factor (MIF) appears to have a molecular weight of about 23,000 and elutes from a Sephadex G-100 column with peak activity in the same fractions as chymotrypsinogen (14). Human mononuclear leukocyte chemotactic factor (15), on the other hand, elutes from Sephadex G-100 coincident with cytochrome $\mathrm{C}$ (molecular weight 12,500 ). The peak activity for OAF is clearly and reproducibly (cf., Fig. 2) between the elution positions of chymotrypsinogen and ribonuclease A (molecular weight 13,700). In addition, both MIF and human mononuclear leukocyte chemotactic factor are heat stable, while OAF is heat labile. Human lymphotoxin (16), which is heat labile, is a considerably larger molecule than OAF, as evaluated by Sephadex G-100 chromatography. We cannot exclude the possibility, however, that OAF represents a variant form of some previously described lymphokine or that OAF has other activities in different biological assay systems than the one used in these studies. Purified guinea pig complement factor $\mathrm{C}^{\prime} 5 \mathrm{a}$, which has chemotactic activity (17), elutes from Sephadex G-100 at about the same position as OAF. However, preliminary experiments ${ }^{2}$ failed to detect any bone-resorbing activity of either guinea pig or human $C^{\prime} 5 \mathrm{a}$.

The biological importance of OAF is not yet known. The production of such a potent stimulator of bone resorption by activated leukocytes in vitro suggests that activation of leukocytes in chronic inflammation might also lead to OAF secretion. If so, it could be responsible for some of the changes in bone resorption seen locally in periodontal disease, arthritis, or osteomyelitis. A factor such as OAF could also be important in neoplastic diseases, particularly those that involve proliferation of lymphoid cells which could themselves produce OAF. We have obtained evidence that lymphoid cell lines derived from patients with hematologic neoplasms produce an

\footnotetext{
${ }^{2}$ L. G. Raisz and R. Snyderman, unpublished results.
}

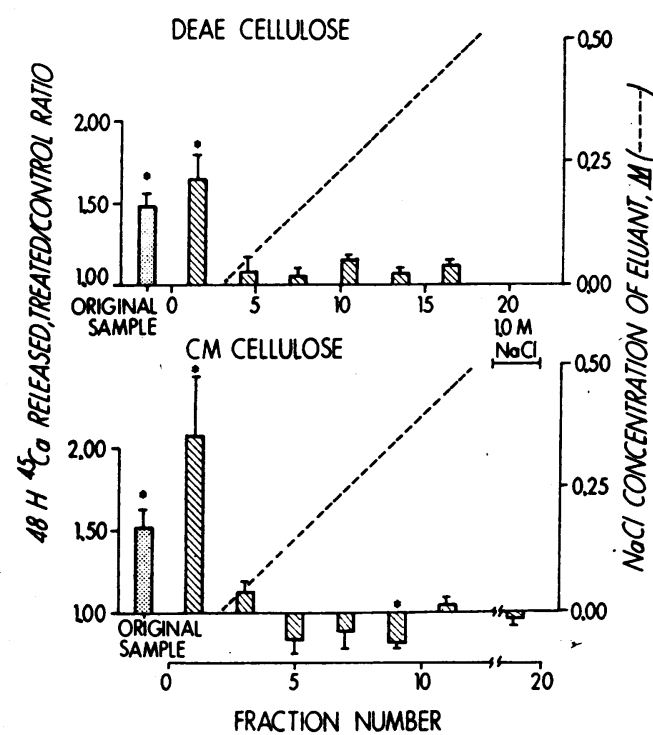

FIgURe 5 Ion exchange purification of OAF. Samples of active fraction OAF from G-100 chromatography were dialyzed against $0.05 \mathrm{M}$ Tris- $\mathrm{HCl}, \mathrm{pH} 7.0$, for DEAE cellulose purification, or against $0.02 \mathrm{M} N$-2-hydroxyethylpiperazine- $N^{\prime}$-2-ethane sulfonic acid, $\mathrm{pH} 7.0$, for $\mathrm{CM}$ cellulose purification. For both ion exchangers, the column $(0.9 \times 10 \mathrm{~cm})$ was washed with starting buffer after applying the same, then eluted with a linear gradient of $\mathrm{NaCl}$, $0 \times-0.5 \mathrm{M}$ in starting buffer. The $\mathrm{CM}$ cellulose column was also washed with $1.0 \mathrm{M} \mathrm{NaCl}$ after elution. Fractions were dialyzed against BGJ, concentrated to the volume of the original sample, and assayed for bone-resorbing activity. Values are mean \pm SEM for four pairs of bones per point. *, significantly different from control $(P<0.05)$.

OAF-like material (18). OAF-like factors could aid the development of bone metastases or promote hypercalcemia in such diseases. Finally, it is possible that in other neoplasms the cellular immunity of the host could result in activation of lymphocytes which produce OAF and affect bone.

\section{ACKNOWLEDGMENTS}

The authors thank Hollis Simmons and Barbara Beeler for technical assistance.

This work was supported in part by National Institutes of Health grants AM 06205, DE 03725, and 5T01 DE $00003-14$, and was aided by grant no. IN-18N from the American Cancer Society.

\section{REFERENCES}

1. David, J. R. 1971. Mediators produced by sensitized lymphocytes. Fed. Proc. 30: 1730.

2. Horton, J. E., L. G. Raisz, H. A. Simmons, J. J. Oppenheim, and S. E. Mergenhagen. 1972. Bone resorbing activity in supernatant fluid from cultured human peripheral blood leukocytes. Science (Wash. D. C.). $177: 793$.

3. Raisz, L. G., and I. Niemann. 1969. Effect of phosphate, calcium and magnesium on bone resorption and 
hormonal responses in tissue culture. Endocrinology. 85 : 446.

4. Cousins, R. J., H. F. DeLuca, and R. W. Gray. 1970. Metabolism of 25-hydroxycholecalciferol in target and nontarget tissues. Biochemistry. 9: 3649.

5. Raisz, L. G., C. L. Trummel, M. F. Holick, and H. F. DeLuca. 1972. 1,25-Dihydroxycholecalciferol: a potent stimulator of bone resorption in tissue culture. Science (Wash. D. C.). 175 : 768.

6. Klein, D. C., and L. G. Raisz. 1970. Prostaglandins : stimulation of bone resorption in tissue culture. Endocrinology. 86 : 1436.

7. Tashjian, A. H., Jr., E. F. Voelkel, L. Levine, and P. Goldhaber. 1972. Evidence that the bone resorptionstimulating factor produced by mouse fibrosarcoma cells is prostaglandin $\mathrm{E}_{2}$. A new model for the hypercalcemia of cancer. J. Exp. Med. 136: 1329.

8. Lowry, O. H., N. J. Rosebrough, A. L. Farr, and R. J. Randall. 1951. Protein measurement with the Folin Phenol Reagent. J. Biol. Chem. 193: 265.

9. Ackers, G. K. 1970. Analytical gel chromatography of proteins. Adv. Protein Chem. 24: 343.

10. Blair, A. J., C. D. Hawker, and R. D. Utiger. 1973. Ectopic hyperparathyroidism in a patient with metastatic hypernephroma. Metab. (Clin. Exp.). 22: 147.

11. Levine, L., and H. Van Vunakis. 1970. Antigenic activity of prostaglandins. Biochem. Biophys. Res. Commun. $41: 1171$.
12. Rasmussen, H. 1960. The purification of parathyroid polypeptides. J. Biol. Chem. 235 : 3442.

13. Hamilton, J. W., F. W. Spierto, R. R. MacGregor, and D. V. Cohn. 1971. Studies on the biosynthesis in vitro of parathyroid hormone. The effect of calcium and magnesium on synthesis of parathyroid hormone isolated from bovine parathyroid tissue and incubation medium. J. Biol. Chem. 246: 3224.

14. Rocklin, R. E., H. G. Remold, and J. R. David. 1972. Characterization of human migration inhibitory factor (MIF) from antigen-stimulated lymphocytes. Cell. Immunol. 5 : 436.

15. Altman, L. C., R. Snyderman, J. J. Oppenheim, and S. E. Mergenhagen. 1973. A human mononuclear leukocyte chemotactic factor: characterization, specificity and kinetics of production by homologous leukocytes. J. Immunol. 110: 801.

16. Russell, S. W., W. Rosenau, M. L. Goldberg, and G. Kunitomi. 1972. Purification of human lymphotoxin. J. Immunol. 109 : 784.

17. Snyderman, R., H. S. Shin, and M. H. Hausman. 1971. A chemotactic factor for mononuclear leukocytes. Proc. Soc. Exp. Biol. Med. 138 : 387.

18. Mundy, G. R., R. A. Luben, L. G. Raisz, J. Oppenheim, and D. N. Buell. 1973. Bone resorbing activity in supernatants from human lymphoid cell lines. Clin. Res. 21: 980 . 